\title{
EXTRINSIC REWARDS, OCCUPATIONAL COMMITMENT, CAREER ENTRENCHMENT AND CAREER SATISFACTION OF DENTISTS
}

\author{
Sakshi Sharma \\ MM Institute of Management, Maharishi Markandeshwar University, India \\ Correspondence: sakshi.vashisht@mmumullana.org
}

\section{ABSTRACT}

Information concerning occupational commitment and career satisfaction of dentists in India is incomplete. Satisfaction of dentists with their profession and commitment towards the profession are important determinants of the future of the dental profession. Therefore, the present study examined the relationship between extrinsic rewards and career entrenchment and occupational commitment of dentists. The study also measured the effect of career entrenchment and occupational commitment on career satisfaction of dentists. Data were collected from 85 dentists of two private dental hospitals of Udaipur city, India. Of the total respondents percent $(n=48) 56$ per cent were male and 44 per cent $(n=37)$ were female. The age of the respondents ranged from 23 to 56 years. 54 per cent of the respondents were employed in their current jobs for less than 10 years and 46 were in the same job for more than 10 years. The data thus collected was analyzed with the help of SPSS 21 using descriptive (mean, standard deviation, percentiles) and inferential statistics (one way ANOVA, post hoc analysis, correlation and multiple regression). The study revealed significant relationship between extrinsic rewards and career entrenchment and affective commitment of dentists. Furthermore, career entrenchment and occupational commitment were found to be significant predictors of career satisfaction. The study puts forward some suggestion for future research in this area

\section{KEYWORDS}

extrinsic rewards; career entrenchment; occupational commitment; career satisfaction; dentists

\section{INTRODUCTION}

One question that is put frequently to dentists is "If you had it to do over again, would you become a dentist? (Chambers 2000) [1] Choosing a career is one of the most important decisions one has to make. Dentists' occupy an important position in the society. The career offers prestige, autonomy, creativity and an opportunity to help others. Before 1980, India had only 39 dental colleges with few dental graduates available for services (Naidu et al. 2014). [2] Today, there is a staggering of 310 dental colleges in India, producing 30,000 graduates every year.[3] Presently, India's dentist to population ratio in urban areas is $1: 8,000$ and in rural areas is 1:50,000.[4] There is unequal distribution of dentists nationally. Dentists in the country prefer to work in urban areas with high standards of living. Thus, $70 \%$ of the dentists are practicing in cities and only $30 \%$ are providing services in the semi-urban and rural areas (Sudhakar 2014).[5]

India is one of the largest producers of dental graduates (Sudhakar 2014). [6] There is a spike in the number of dental colleges in India and students graduating out of these colleges every year. Owing to the huge oversupply of dentists, it is expected that India will have more than 100,000 dentists' surplus by 2020 (Sudhakar 2014).[7] There is a gradual increase in the number of dental graduates in the country. The alarming increase can be attributed to various factors such as poor manpower planning, mushrooming of dental colleges, reliance on faulty statistics, absence of any specific design or policy planning and inefficient regulatory bodies (Sudhakar 2014).[8] The upsurge in dental graduates can limit the job prospects for 
the new graduates. Dagli and Dagli (2015) [9] reported that the current scenario pose a threat to the professional integrity of the fresh dental graduates. Dentists in India struggle in terms of placement, poor working conditions, poor income and high workload (Malhotra et al. 2016). [10] In their study Bailoor et al. (2014) [11] suggested that dental surgeons are shifting their professions due to unemployment. The percentage of dentist committing suicide is also on the rise because of unemployment and a sense of hopelessness (Dagli \& Dagli 2015). [12]

Dentistry has been identified as one of the most stressful professions (Luzzi \& Spencer, 2011). [13] The satisfaction of the dentists with their profession and commitment towards the profession are important determinants of the future of the dental profession. Satisfied providers are more likely to recommend career in dental hygiene to others; satisfaction is highly related to job and career attrition and is ultimately related to job performance and patient care (Bader \& Sams 1992). [14] Low job satisfaction of dentist can lead to high turnover with resultant loss of productivity and reduced quality of patient care (Luzzi et al. 2005). [15] Fulfillment in the profession is important. Thus, the present study is undertaken to ascertain empirically the level of career entrenchment, career satisfaction and occupational commitment of dental practitioners. The study will ascertain the relationship of extrinsic rewards with career entrenchment and occupational commitment of dentists and effect of these factors on their career satisfaction.

\section{CAREER ENTRENCHMENT}

According to Carson et al. (1996) [16] career entrenchment is 'employees' feelings of immobility resulting from substantial economic and psychological investments in a career that makes change difficult". Rodrigues (2009, as cited in Scheible \& Bastos 2013) explains "entrenched individuals as one who are stuck in their careers (or organization) by necessity.[17] So, one can assume that these individuals are not very concerned with productivity, and not engaged into contributing, through their work to future generations". Career entrenchment has been considered as an important indicator of permanence of individuals in their profession and/or organization. Entrenchment is a metaphor based on Becker's (1960, as cited in Scheible \& Bastos 2013) [18] side-bets theory which states that individual stay in an organization or career even if they do not desire, as it seems more secure. This cognition occurs when individuals do not adapt, are not motivated and cannot find alternative jobs. Therefore, they do not leave the trench (organization or profession) where they feel protected (Scheible \& Bastos 2013).[19] Carson and Carson (1995) [20] define three dimensions of career entrenchment: career investments, emotional costs and limitedness of career alternatives. Career investments is the accumulated investments one has made in one's career success which would be lost or deemed worthless if one pursues a new career. One invests a substantial amount of money, time and effort in their present careers. These accumulated investments can be lost if one changes career. Individuals may also feel that they risk losing accumulated benefits such as high income and status in the present organization (Zacher, Ambiel \& Noronha 2015).[21] Emotional costs, focuses on the anticipated emotional costs that would be associated with pursuing a new career. It is the expected socio-economic risks associated with pursuit of a new career such as disruption of friendship with colleagues (Zacher, Ambiel \& Noronha 2015).[22] Limitedness of career alternatives, is associated with lack of available options for pursuing a new career. Carson, Carson and Bedeian (1995) [23] stated the symptoms of entrenchment may include social stigma associated with career withdrawal; fear that age and skillspecificity will limit employability; unwillingness to give up the stature acquired in current occupation; and scepticism about future earning ability. With no alternatives, the employees' freezes in their current occupation and thus becomes entrenched. Carson, Phillips and Roe (1996) [24] on the basis of two constructs i.e. career entrenchment and career satisfaction, categorized individuals into four domains viz. entrapped, contended immobile, career changer and voluntary careerist. Entrapped are individuals who score high on career entrenchment and low on career satisfaction. Contended immobile are those who score high on both the constructs. Career changers are those individuals who score low on both the constructs. Voluntary careerists are individuals who score low on career entrenchment and high on career satisfaction.

\section{OCCUPATIONAL COMMITMENT}

Occupational commitment refers to the "psychological link between an individual and his/her occupation that is based on affective reaction to that occupation" (Lee, Carswell \& Allen 2000). [25] Goswami, Mathew and Chadha (2007) [26] stated that employee loyalty is shifting from organization to one's occupation because of various changes happening in the business environment such as job rotation, employee resizing, organizational 
restructuring, and job insecurity. Individuals with high occupation commitment identify strongly with and have positive feeling towards their occupation (Ciftcioglu 2011). [27] Meyer and Allen (1991) [28] on the basis of threedimensional structure of organizational commitment conceptualized occupational commitment as a threedimensional construct. The three dimensions consist of affective, continuance and normative commitment. Affective commitment is the emotional bond an employee develops towards the organisation in which he works. When affective commitment is strong employees stay with the organisation and identifies with the values that organisation upholds. Continuance commitment is the cost the employee associates with leaving or staying in the organisation. When the employee feels the cost of staying is less then they stay and vice versa. Normative commitment is the obligation employee feels towards the organisation which he works. They feel that they need to stay in the organisation for various reasons (Brown 2003).[29] At any point of time an employee can have these commitments in varied degrees (Brown 2003). Although numerous researchers have studied organizational/occupational commitment (Chen et al. 2014; Kaldenberg et al. 1995; Merk \& Turkmen 2015), [30][31][32] we found no study which has been conducted to study occupational commitment of dentists practicing in India. Occupation is a major focus of one's life and occupational commitment keeps one's relationship with the job or with the organization (Bakan et al. 2012).[33] It has an important consequence on employees' work related behaviour such as turnover (Wang et al. 2011) [34], absenteeism (Mowday et al. 1982) [35], and job performance (Undale \& Pande 2016) [36].

Because, continuance commitment echoes to the term entrenchment as both of them refers to staying in the organization out of need and not desire (Scheible \& Bastos 2013) [37], therefore only affective and normative dimensions of occupational commitment will be studied in the present study.

\section{CAREER SATISFACTION}

Career satisfaction is the satisfaction that individual derives from the intrinsic and extrinsic aspects of their careers, including pay, advancement, and developmental opportunities (Greenhaus, Parasuraman, \& Wormley 1990). [38] It implies doing a job one enjoys, doing it well and being rewarded for one's efforts (Brikend 2011). [39] Researchers in the past have found various factors that influence career satisfaction of individuals such as income
(Poon 2004) [40], promotion opportunities (Bozionelos 1996) [41], tenure (Judge at al. 1995) [42], supervisory support and recognition (Greenhaus, Parasuraman, \& Wormley 1990) [43] and challenging and visible jobs (Richardsen, Michelsen, \& Burke 1997) [44]. Jankiram et al. (2017) in their study among 580 public health dentists in India reported that the career satisfaction was low among dentists due to job insecurity and unemployment. The researchers reported that nearly half of the study respondents felt that they did not achieve the desired accomplishment in the profession. [45] Similar results were reported by Kaipa et al. (2015) in their study on dental practitioners registered with Indian Dental Association. The researchers found medium level of satisfaction among the respondents with the dental profession as a career.[46]

\section{EXTRINSIC REWARDS}

Motivating employees is responsibility of an organization. Employees put maximum efforts in their work when they feel that they are treated fairly. Porter and Lawler (1968) [47] distinguishes between two categories of rewards: intrinsic rewards and extrinsic rewards. Intrinsic rewards are defined as the satisfaction one derives from doing a job. On the other hand, extrinsic rewards are the tangible benefits obtained as a result of doing the job. Extrinsic rewards can take forms such as money. Extrinsic rewards can be social and organizational rewards. Social rewards are those rewards that are derived from interactions with others (like co-workers, superiors) on the job. Organizational rewards are the tangible rewards such as pay, incentives, allowances, promotion, recognition, and other organizational benefits. Individuals are extrinsically motivated when they engage in work in order to obtain some goal that is apart from the work itself (Amabile 1993). [48] Extrinsic rewards raise employees' effort in the job. It has a significant impact on job satisfaction of employees and also increases employee retention (Ajmal et al. 2015).[49] Satisfied employees also show great loyalty and commitment towards the organization. Researchers have found significant relationship between rewards and affective commitment (Kuvaas 2006; Lee et al. 2012; Miao et al. 2013) [50] [51][52], normative commitment (Lee et al. 2012; Korir \& Kipkebut 2016; Miao et al. 2013)[53][54][55] and continuance commitment (Lee et al. 2012; Umoh et al. 2014) [56][57].

Based on the above arguments, the study proposes following hypotheses: 
- Hal: There is a significant negative relationship between extrinsic rewards and career entrenchment such that dentists with high extrinsic rewards will experience less entrenchment.

- Ha2: There is a significant positive relationship between extrinsic rewards occupational commitment (affective commitment and normative commitment) such that dentists with high extrinsic rewards will experience higher occupational commitment.
- Ha3: There is a significant positive relationship between occupational commitment and career satisfaction.

- Ha4: There is a significant negative relationship between career entrenchment and career satisfaction.

- On the basis of the above literature and formulated hypotheses, the hypothetical framework for the study is as under:

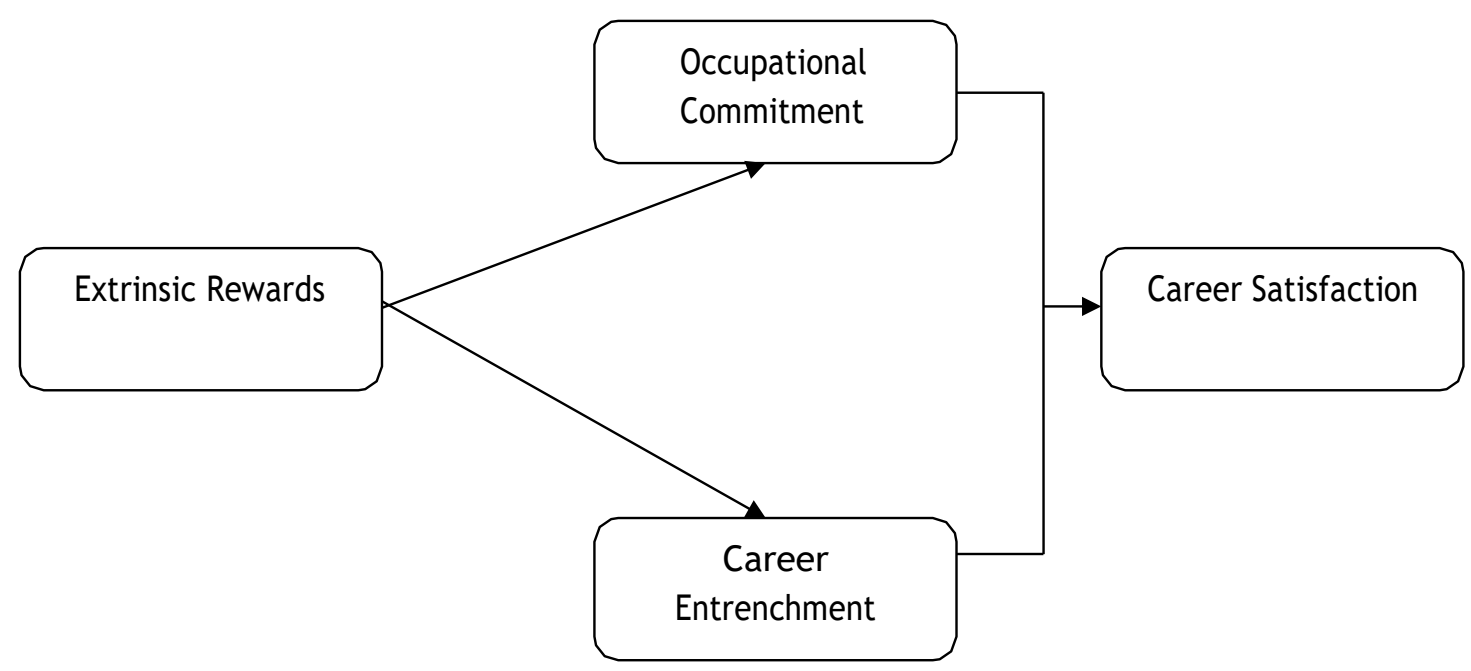

\section{METHODS}

\section{PARTICIPANTS AND PROCEDURES}

The questionnaire-based survey was conducted during April 2018 and May 2018. The study was conducted among two private dental hospitals of Udaipur city, India. The final respondents were selected using convenience and judgment sampling techniques. A total of 102 dental practitioners were approached for participation in the study. A total of 85 dentists completed the questionnaire for a response rate of 83 per cent. Of the total respondents percent $(n=48) 56$ per cent were male and 44 per cent $(n=37)$ were female. The age of the respondents ranged

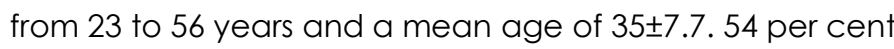
respondents had been employed in their current jobs for less than 10 years and 46 had been in the same job for more than 10 years. The data thus collected have been analyzed with the help of SPSS 21 using descriptive and inferential statistics.

\section{MEASURES}

Career entrenchment: To gauge career entrenchment, scale developed by Carson, Carson and Bedeian (1995) [57] was used. The scale is a 12-item multi-dimensional instrument. It measures three dimensions of career entrenchment: career investments (4 items), emotional costs (4 items) and limitedness of career alternatives (4 items). The responses were recorded on a five-point scale ( 1 = strongly disagree to $5=$ strongly agree).

\section{Occupational commitment: Occupational} commitment was measured using a scale developed by Meyer, Allen and Smith (1993). [58] The scale comprises 
eighteen items rated on a five-point scale $(1=$ strongly disagree to $5=$ strongly agree). It measures three form of occupational commitment: affective commitment 16 items), normative commitment ( 6 items) and continuance commitment (6 items).

Career Satisfaction Scale: Career satisfaction was measured using a scale developed by Greenhaus, Parasuraman, and Wormley (1990).[59] The scale comprises five items rated on a five-point scale ( 1 = strongly disagree to 5 = strongly agree). One sample item is "I am satisfied with the progress I have made toward meeting my overall career goals."

Extrinsic Rewards: The short form of Minnesota Satisfaction Questionnaire (MSQ) (Weiss, Dawis, England \& Lofquist 1967) [60] was used to study extrinsic rewards. Table 1 lists the extrinsic rewards MSQ scales used in the present study.

\section{DATA ANALYSIS}

\section{DESCRIPTIVE STATISTICS}

Extrinsic Rewards: scores on extrinsic rewards (Table 2) ranged between 15 and 28 . The mean score was found to be 21.34 and the standard deviation was reported as 2.88 . $50 \%$ of the dentists scored below 22 and $50 \%$ scored above 22. As per the quartile deviations, $25 \%$ of the respondents scored below the score of 19 and $25 \%$ scored between 23 and 28. Career Entrenchment: scores on career entrenchment (Table 2) ranged between 22 and 51. The mean score was 37.29 (2.88). $50 \%$ of the dentists scored below the score of 38 . As per the quartile deviations, $25 \%$ of the respondents scored below the score of 34 and $25 \%$ scored between 40 and 51. Occupational Commitment: scores on occupational commitment (Table 2) ranged between 22 and 48 . The mean score was 35.74 with 5.31 standard deviation of was reported as 2.88 . $50 \%$ of the dentists scored below 36 and $50 \%$ scored above 36. As per the quartile deviations, $25 \%$ of the respondents scored below the score of 32 and $25 \%$ scored between 40 and 48 . Career Satisfaction: scores on career satisfaction (Table 2) ranged between 6 and 20 . The mean score was found to be 13.14 (3.51). 50\% of the dentists scored below 13 and $50 \%$ score above 13. As per the quartile deviations, $25 \%$ of the respondents scored below the score of 10 and $25 \%$ scored between 16 and 20 .

\section{EXTRINSIC REWARDS, CAREER ENTRENCHMENT AND OCCUPATIONAL COMMITMENT}

In order to find out the relationship between extrinsic rewards and career entrenchment and occupational commitment, Pearson correlation coefficient was employed and the results are shown in Table 3. Extrinsic rewards was found to be significantly and negatively related with career entrenchment $\left(r=-.36^{* *}, p<.01\right)$. Furthermore, from the results of the table 3 , extrinsic rewards were also found to be significantly and positively related with affective commitment $\left(r=.48^{* *}, p<.01\right)$ and total occupational commitment $\left(r=.37^{* *}, p<.01\right)$. However, no significant relationship was found between extrinsic rewards and normative commitment $r=.02^{* *}, p=n . s$.).

To test hypothesis $\mathrm{Hal}$ and $\mathrm{Ha} 2$, the respondents were classified into three groups (Table 4) based on the scores obtained in the questionnaire as those with a) low extrinsic rewards - score < (Mean-0.5 S.D.); average extrinsic rewards; b) average extrinsic rewards: score between (Mean-0.5 S. D.) and (Mean + 0.5 S.D.); and C) high extrinsic rewards -score > (Mean+0.5 S.D.). One-way ANOVA was employed to find whether there is any significant difference in occupational commitment and career entrenchment of dentists at three levels of extrinsic rewards i.e. low, average and high.

One of the assumptions of the one-way ANOVA is that variances of the groups should be similar. Table 5 shows the results of Levene's Test of Homogeneity of Variances, which tests for similar values. The sig. value was found to be less than 0.05 for career entrenchment. Thus, the assumption of homogeneity of variance was not met and therefore two robust tests (Brown-Forsythe and Welch) were conducted. Table 6 shows the results of the two tests. From the details of the table, $F$ value was found to be significant ( $F=5.827$, $\mathrm{p}<0.05)$. The results imply that there is significant difference in career entrenchment of dentists at various levels of extrinsic rewards. Since the groups were found to be significantly different, the post hoc test was employed to identify the pair of groups that contributed to significant differences. Table 8 shows the results of Games-Howell post hoc analysis. The details presented in the table revealed that the p-value between low and average and low and high groups was less than 0.05, implying that the mean scores between low and average and low and high groups differed significantly at the $5 \%$ level of significance. However, the p-value for average and high groups was found to be greater than 0.05, implying that there were no significant differences among these groups. The results 
imply that career entrenchment differed significantly among dentist with low and average and low and high extrinsic rewards, however, does not differ significantly among dentists with average and high extrinsic rewards. As shown in Figure 1, career entrenchment was highest among dentists with low extrinsic rewards, followed by dentists with average extrinsic rewards. Career entrenchment was least among dentists with high extrinsic rewards. Thus, hypothesis Hal was accepted.

For occupational commitment, from the results of Levene's Test of Homogeneity of Variances, significance value was found to be greater than 0.05 (Table 5). Thus, the assumption of homogeneity of variance was supported. Table 7 shows the results of ANOVA analysis. F values were found to be significant for occupational commitment $(\mathrm{F}=6.206, \quad \mathrm{p}<0.05)$. The results suggested significant differences in occupational commitment of dentists at low, average and high levels of extrinsic rewards. Since the groups were found to be significantly different, the post hoc test was employed to identify the pair of groups that contributed to significant differences. Table 9 shows the results of Tukey HSD post hoc analysis. The details presented in the table revealed that the p-value between low and high and average and high groups was less than 0.05, implying that the mean scores between low and high and average and high groups differed significantly at the $5 \%$ level of significance. However, the p-value for low and average groups was found to be greater than 0.05, implying that there were no significant differences among these groups. The results imply that occupational commitment differed significantly among dentists with low and average and low and high extrinsic rewards, however, does not differ significantly among dentists with average and high extrinsic rewards. As shown in Figure 2, occupational commitment was highest among dentists with high extrinsic rewards, followed by dentists with average extrinsic rewards and dentists with low extrinsic rewards. Thus, hypothesis Ha2 was accepted.

\section{CAREER ENTRENCHMENT AND OCCUPATIONAL COMMITMENT EFFECTS ON CAREER SATISFACTION}

Multiple regression analysis was used to study the impact of career entrenchment and occupational commitment on career satisfaction. Based on the standardized coefficients of each of the independent variable, the impact on the dependent variable was assessed. From Table 10, it was noted that Career Entrenchment ( $\beta=-.681$ ) was more influential factor in explaining the career satisfaction of dentists. Occupational Commitment $(\beta=.175)$ was also found to be a significant predictor of career satisfaction of dentists. The direction of variables was consistent with the prior expectations. As noted in Table 11, R2 was .57, which indicated that approximately $57 \%$ of the variation in career satisfaction could be explained by both of the factors combined. The significant $F$ ratio $(F=54.63, p<0.05)$ indicate that the results of the regression model could have hardly occurred by chance. Hence, Hypothesis Ha3 and Ha4 were accepted.

FIGURE 1: CAREER ENTRENCHMENT AT VARIED LEVELS OF EXTRINSIC REWARDS

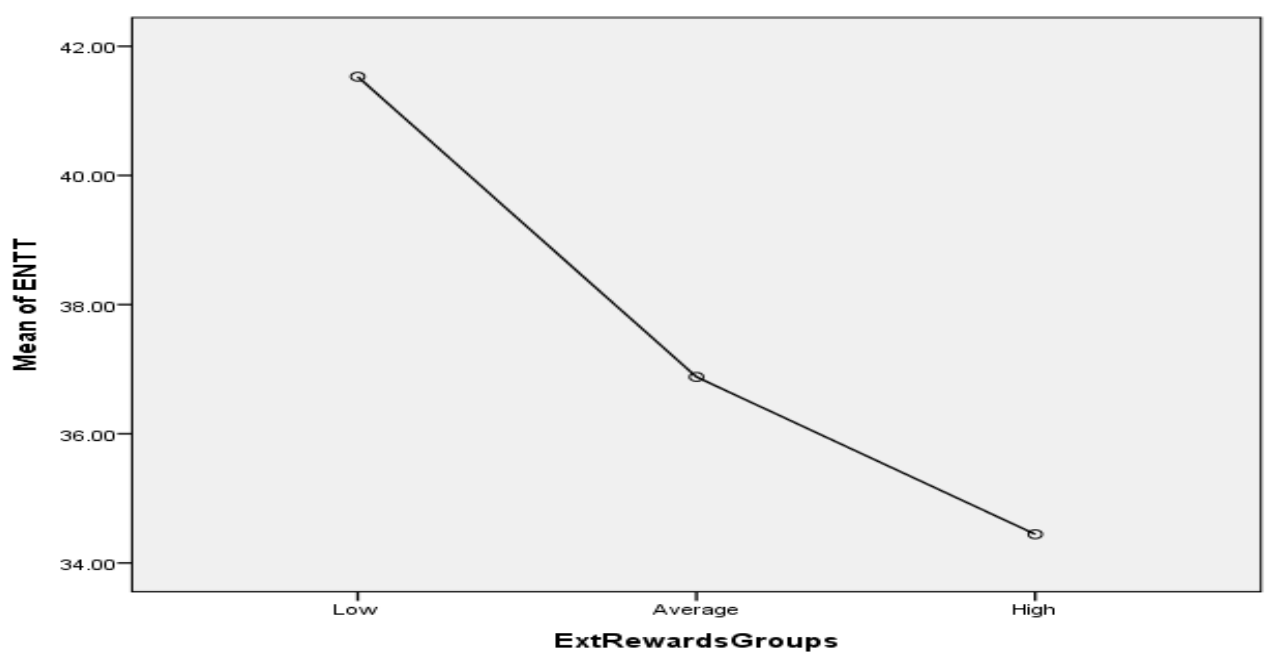




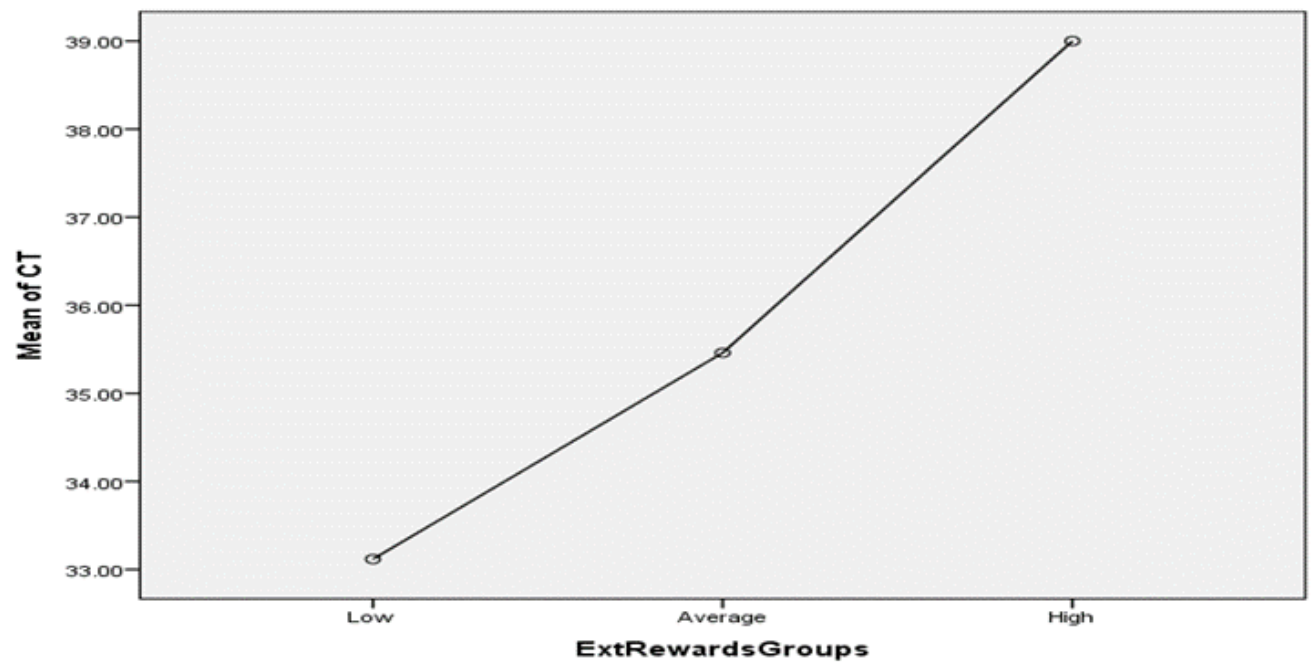

\section{DISCUSSION AND CONCLUSION}

The research results of the study show significant output. It was found in the study that extrinsic rewards have much importance to improve occupational commitment of dentists and reduce career entrenchment. The study found significant positive relationship between extrinsic rewards and affective commitment. No significant relationship was found between extrinsic rewards and normative commitment. The present study also reported significant negative relationship between extrinsic rewards and career entrenchment. Dentists were grouped on the basis of their scores on extrinsic rewards into three categories viz. low, average and high. Occupational commitment was found to be significantly high among groups with high extrinsic rewards as compared to dentists with low extrinsic rewards. Also, dentists with high extrinsic rewards experienced relatively less career entrenchment as compare to dentists with average extrinsic rewards and low extrinsic rewards.

The results of the present study contribute to discussions on consequences of rewards on overall satisfaction and commitment of employees. Motivation is a driver of career success and rewards motivate individuals. Rewards have an important place in the quality incentive structure. If dentists are rewarded appropriately with salaries, incentives, increments; have opportunities for advancement; perceive policies as fair and transparent etc., they may show more commitment to the occupation. Also, such rewards may make them feel less entrapped in their career. Furthermore, as seen from the results of the regression analysis of the present study, higher commitment and less career entrenched dentists may also experience higher career satisfaction.

The present study was important because internationally the relationship between rewards, commitment and career satisfaction have been extensively investigated. However, such research has rarely been conducted on dentists working in India. The alarming increase in dental workforce in the country and rise of unemployment put emphasis on designing the jobs in a manner which is seen as extrinsically rewarding. By strategically managing rewards, the dentistry profession can capitalize on the benefits of committed and satisfied workforce. Since rewards have strong implications on the satisfaction of dentists, policy makers and management should emphasize on different types of extrinsic rewards. Extrinsic rewards that are important to dentists must be the centre of interest of administration authorities. These rewards can influence dentists' job satisfaction, improve retention (Ajmal et al. 2015) [61] and increase organizational commitment (Lee et al. 2012) [62]. 


\section{LIMITATIONS AND RECOMMENDATIONS}

The limitation of this study is its small sample size and the sampling technique used. This may limit the generalizability of the results. More studies can be carried out in the future with a larger sample size. Furthermore, the study only examined intrinsic rewards. Studies in the future should combine both intrinsic and extrinsic rewards and study their impact on dentists' overall satisfaction. A better understanding of these factors can help to optimise the dentistry profession. In addition, the study is cross- sectional design and therefore was unable to determine the relationship between the studied variables over a period of time. Therefore, it is recommended that such study is repeated in the form of a longitudinal research to determine the impact of rewards on career entrenchment, occupational commitment and overall career satisfaction. In addition, the respondents of the study were from private hospitals only. Future research can be done on dentists working in public hospitals. A comparative study of public and private can also be undertaken.

\section{REFERENCES}

[1] Chambers DW. The role of dentists in dentistry. Journal of Dental Education 2000; 65(12): 1430-1440.

[2] Naidu GM, Prasad G, Kandregula, CR, Babburi S, KVNR P. Choosing public health dentistry as a career: A cross-sectional study. Journal of Clinical and Diagnostic Research 2014; 8(2): 199-202.

[3] [4] Times of India (2016, Dec 24). Scarcity of dentists in rural areas. Available

<https://timesofindia.indiatimes.com/city/hyderabad/ scarcity-of-dentists-in-rural-areas- president-pranabmukherjee/articleshow/56150881.cms> (Accessed 06/02/18)

[5][6] [7] [8] Sudhakar V. Dental manpower planning in India: current scenario and future projections for the year 2020. International Dental Journal 2014; 64 (2): 6267.

[9] Dagli N, Dagli R. Increasing unemployment among Indian dental graduates-high time to control dental manpower. Journal of International Oral Health 2015; $7(3):$ i-ii.

[10] Malhotra R, Bhola K, Khandelwal N, Bhola R. Meaningfulness among Indian dentists: An interoccupation analysis. Dent Oral Craniofac Res 2 2016: DOI: 10.15761/DOCR.1000183.
[11] Bailoor DN, Naidu G, Jhingan A, Shukla A, Beohar $K$. The future of oral physicians-A perplexing enigma? An Indian Survey. Journal of Dental and Medical Sciences 2014;13(4): 71-75.

[13] Luzzi L, Spencer AJ. (2011). Job satisfaction of the oral health labour force in Australia. Aust Dentistry Journal; 56: 23-32.

[14] Bader JD, Sams DH. Factors associated with job and career satisfaction among dental hygienists 1992. Journal of Public Health Dentistry; 52(2): 43-51.

[15] Luzzi L, Spencer AJ, Jones K, Teusner D. Job satisfaction of registered dental practitioners. Aust Dentistry Journal 2005; 50: 179-185.

[16] [24] Carson KD, Carson PP, Roe CW. A career entrenchment model: Theoretical development and empirical outcomes. Journal of Career Development 1996; 22: 273-286.

[17] [18] [19] [37] Scheible ACF, Bastos AVB. An examination of human resource management practices' influence. Brazilain Administration Review 2013; 10(1): 57-76

[20] [23] [57] Carson KD, Carson PP. Development and construct validation of a career entrenchment measure. Journal of Occupational and Organizational Psychology 1995; 68: 301-320.

[21] [22] Zacher H, Ambiel, RAM, Noronha, APP. Career adaptability and career entrenchment. Journal of Vocational Behavior 2015; 88(1): 164173.doi: 10.1016/j.jvb.2015.03.006

[25] Lee K, Carswell J, Allen N. A Meta-Analytic Review of Occupational Commitment: Relations with Person and Work-Related Variables. Journal of Applied Psychology 2000; 85(5): 799-811.

[26] Goswami S, Mathew M, Chadha, NK. Differences in occupational commitment among scientists in Indian defence, academic, and commercial R\&D organizations. Vikalpa 2007; 32(4): 13-27.

[27] Ciftcioglu A. Investigating occupational commitment and turnover intention relationship with burnout syndrome. Business and Economics Research Journal 2011; 2(3): 109- 119.

[28] Meyer JP, Allen NJ. A three-component conceptualization of organizational commitment. Human Resource Management Review 1991; 1: 61-89.

[29] Brown BB. Employees' organisational commitment and their perception of supervisor's relations-oriented and task oriented leadership 
behaviours; Available:

<https://vtechworks.lib.vt.edu/bitstream/handle/10919

/26676/BarbaraBrown-4-22-03.pdf? sequence=1>

(Accessed 17/04/18)

[30] Chen M-L, SU Z-Y, Lo C-L, Chiu C-L, Hu Y-H, Shieh T$Y$. An empirical study on the factors influencing the turnover intentions of dentists in hospitals in Taiwan. Journal of Dental Sciences 2013; 9: 332-344.

[31] Kaldenberg DO, Becker BW, Zvonkovic A. Work and commitment among young professional: A study of male and female dentists. Human Relations 1995; 48(11): 1355- 1377.

[32] Merk G, Turkmen AO. In health workers leadership and organizational commitment. Journal of International Health Sciences and Management 2015; $1(1): 21-33$.

[33] Bakan I, Ersahan B, Buyukbese T, Kefe I. The research preferences and occupational commitment of academic staff. Procedia-Social and Behavioral Sciences 2012; 47: 449-454.

[34] Wang L, Tao H, Ellenbecker, CH, Liu X. Job satisfaction, occupational commitment and intent to stay among Chinese nurses: a cross-sectional questionnaire survey. JAN 2011; 68(3): 539-549.

[35] Mowday R, Porter L, Steers R. Employee organization linkages: The psychology of commitment, absenteeism, and turnover. New York, NY: Academic Press; 1982.

[36] Undale, S., Pande, M. Effect of organizational and occupational commitment on satisfaction and performance of medical representatives. SM's International E-Journal on Ongoing Research in Management \& IT 2016.

[38][43] [59] Greenhaus JH, Parasuraman A, Wormley WM. Effects of race on organizational experiences, job performance evaluations, and career outcomes. Academy of Management Journal 1990; 33(1): 64-86.

[39] Brikend A. Job satisfaction - A literature review. Management Research and Practice 201 1; 3(4): 7786.

[40] Poon JML. Career Commitment and Career Success: Moderating Role of Emotion Perception. Career Development International 2004; 9 (4): 374-390.

[41] Bozionelos N. Organizational Promotion and Career Satisfaction. Psychological Reports 1996; 79 (22): 371-375.
[42] Judge TA, Cable DM, Boudreau JW, Bretz RD. An empirical investigation of the predictors of executive career success. Personnel Psychology 1995; 48 (3): 485-519.

[44] Richardsen AM, Michelsen A, Burke RJ. Work experiences and career and job satisfaction among professional and managerial women in Norway. Scandinavian Journal of Management 1997; 13 (2): 209-218.

[45] Jankiram C, Joseph J, Antony B. Career satisfaction among dental health public health specialists in India- A cross-sectional survey. Journal of Clinical \& Diagnostic Research 2017; 11 (1): 97-101.

[46] Kaipa S, Pydi S, Kumar RVS, Sirinivasulu G, Darsi VR, Sode M. Career satisfaction among dental practitioners in Srikakulam, India. Journal of International Society of Preventive \& Communist Dentistry 2015; 5(1): 40-46.

[47] Porter LW, Lawler, EE. (1968). Managerial Attitudes and Performance. Homewood, IL: Dorsey Press.

[48] Amabile TA. Motivational synergy: Toward new conceptualizations of intrinsic and extrinsic motivation in workplace. Human Resource Management Review 1993; 3 (3):185-201.

[49] [61] Ajmal A, Bashir M, Abrar M, Khan MM, Saqib S. The effects of intrinsic and extrinsic rewards on employee attitudes: Mediating role of perceived organizational support. Journal of Service Science and Management 2015; 8: 461-470.

[50] Kuvaas B. Work performance, affective commitment, and work motivation: The roles of pay administration and pay level. Journal of Organizational Behaviour 2006; 27: 365-385.

[51] [53] [56] [62] Lee C-H, Fu Jen C-Y. The relationship between reward system and organizational commitment of fitness club employees in Taiwan. North American Society for Sport Management Conference 2012; 408-409. Available <https://www.nassm.org/files/conf_abstracts/2012098.pdf> (Accessed 12/05/18)

[52] [55] Miao Q, Newman A, Sun Y, Xu L. What factors influence the organizational commitment of public sector employees in China? The role of extrinsic, intrinsic and social rewards. The International Journal of Human Resource Management 2013; 24(17): 32623280. 
[54] Korir I, Kipkebut D. The effect of reward-

management on employee commitment in the

universities in Nakuru County-Kenya. Journal of Human

Resource Management 2016; 4(4): 37-48.

[57] Umoh, G. I., Amah, E. , Wokocha, I. H. Employee benefits and continuance commitment in the Nigerian manufacturing industry. IOSR Journal of Business and Management 2014; 16(2): 69-74.

[58] Meyer JP, Allen NJ, Smith CA. Commitment to organizations and occupations: Extension and test of a three-component conceptualization. Journal of Applied Psychology 1993; 78(4): 538-551.

[60] Weiss DJ, Dawis RV, England GW, Lofquist LH. Manual for the Minnesota Satisfaction Questionnaire. University of Minnesota, Minneapolis. 


\section{TABLE 1: LIST OF EXTRINSIC FACTORS}

\begin{tabular}{|l|l|}
\hline Co-workers & The way my co-workers get along with each other \\
\hline Recognition & The praise I get for doing a good job \\
\hline Advancement & The chances for advancement on this job \\
\hline $\begin{array}{l}\text { Supervision-human } \\
\text { relations }\end{array}$ & The way my boss handles his/her workers \\
\hline Supervision-technical & The competence of my supervisor in making decisions \\
\hline Company policies & The way company policies are put into practice \\
\hline Compensation & My pay and the amount of work I do \\
\hline Working conditions & The working conditions \\
\hline
\end{tabular}

\section{TABLE 2: DESCRIPTIVE STATISTICS FOR STUDY VARIABLES}

\begin{tabular}{|c|c|c|c|c|c|c|}
\hline \multirow[t]{2}{*}{ Statistics } & \multirow{2}{*}{$\begin{array}{l}\text { Extrinsic } \\
\text { Rewards }\end{array}$} & \multirow{2}{*}{$\begin{array}{l}\text { Career } \\
\text { Entrenchment }\end{array}$} & \multicolumn{3}{|c|}{ Occupational Commitment } & \multirow{2}{*}{$\begin{array}{l}\text { Career } \\
\text { Satisfaction }\end{array}$} \\
\hline & & & $\begin{array}{l}\text { Affective } \\
\text { Commitment }\end{array}$ & $\begin{array}{l}\text { Normative } \\
\text { Commitment }\end{array}$ & $\begin{array}{l}\text { Occupational } \\
\text { Commitment } \\
\text { (Total) }\end{array}$ & \\
\hline N & 85 & 85 & 85 & 85 & 85 & 85 \\
\hline Mean & 21.34 & 37.29 & 16.36 & 19.37 & 35.74 & 13.14 \\
\hline S.D & 2.88 & 6.20 & 3.97 & 3.39 & 5.31 & 3.51 \\
\hline Range & 13 & 29 & 16 & 16 & 26 & 14 \\
\hline Minimum & 15 & 22 & 10 & 10 & 22 & 6 \\
\hline Maximum & 28 & 51 & 26 & 26 & 48 & 20 \\
\hline \multicolumn{7}{|l|}{ Percentiles } \\
\hline 25 & 19 & 34 & 14 & 17 & 32 & 10 \\
\hline 50 & 22 & 38 & 15 & 20 & 36 & 13 \\
\hline 75 & 23 & 40 & 19 & 22 & 40 & 16 \\
\hline
\end{tabular}


TABLE 3: CORRELATION COEFFICIENT BETWEEN EXTRINSIC REWARDS AND CAREER ENTRENCHMENT AND OCCUPATIONAL COMMITMENT

\begin{tabular}{|l|l|l|}
\hline \multicolumn{2}{|l|}{ Extrinsic rewards } & Correlation \\
\hline \multicolumn{2}{|l|}{ Career entrenchment } & $-.367^{* *}$ \\
\hline \multirow{2}{*}{ Occupational commitment } & Affective Commitment & $.481^{* *}$ \\
\cline { 2 - 3 } & Normative Commitment & .027 \\
\cline { 2 - 3 } & Occupational Commitment & $.377^{* *}$ \\
\hline
\end{tabular}

\section{TABLE 4: CLASSIFICATION OF DENTISTS}

\begin{tabular}{|l|l|l|l|l|l|l|}
\hline \multirow{2}{*}{} & \multicolumn{2}{l}{ Classification } \\
\cline { 2 - 7 } & \multicolumn{2}{|l|}{ Low } & \multicolumn{2}{l|}{ Average } & \multicolumn{2}{l|}{ High } \\
\cline { 2 - 7 } & N & $\%$ & N & $\%$ & N & $\%$ \\
\hline Extrinsic rewards & 17 & 20 & 50 & 58.8 & 18 & 21.2 \\
\hline
\end{tabular}

TABLE 5: TEST OF HOMOGENEITY OF VARIANCES

\begin{tabular}{|l|l|l|l|l|}
\hline & Levene Statistic & df1 & df2 & Sig. \\
\hline Career Entrenchment & 15.065 & 2 & 82 & .000 \\
\hline Occupational Commitment & 2.994 & 2 & 82 & .088 \\
\hline
\end{tabular}

TABLE 6: ROBUST TEST OF EQUALITY OF MEANS - CAREER ENTRENCHMENT

\begin{tabular}{|l|l|l|l|l|l|}
\hline \multicolumn{2}{|c|}{} & Statistic & df1 & df2 & Sig. \\
\hline $\begin{array}{l}\text { Career } \\
\text { entrenchment }\end{array}$ & Welch & 5.827 & 2 & 26.81 & .008 \\
\cline { 2 - 6 } & Brown-Forsythe & 4.578 & 2 & 31.66 & .018 \\
\hline
\end{tabular}

TABLE 7: OCCUPATIONAL COMMITMENT AT VARIED LEVELS OF EXTRINSIC REWARDS

\begin{tabular}{|l|l|l|l|l|l|}
\hline Sources of variance & Sum of Squares & Df & Mean Square & F & Sig. \\
\hline Between Groups & 273.443 & 2 & 136.722 & 5.340 & .007 \\
\cline { 1 - 4 } Within Groups & 2099.662 & 82 & 25.606 & & \\
\cline { 1 - 5 } Total & 2373.106 & 84 & & & \\
\hline
\end{tabular}


TABLE 8: GAMES HOWELL POST HOC ANALYSIS FOR COMPARISON OF CAREER ENTRENCHMENT AT VARIED LEVELS OF EXTRINSIC REWARDS

\begin{tabular}{|c|c|c|c|c|c|c|}
\hline \multirow{2}{*}{$\begin{array}{l}\text { (I) Ext. } \\
\text { Rewards } \\
\text { Groups }\end{array}$} & \multirow{2}{*}{$\begin{array}{l}\text { (J) Ext. } \\
\text { Rewards } \\
\text { Groups }\end{array}$} & \multirow{2}{*}{$\begin{array}{l}\text { Mean Difference } \\
(\mathrm{I}-\mathrm{J})\end{array}$} & \multirow[t]{2}{*}{ Std. Error } & \multirow[t]{2}{*}{ Sig. } & \multicolumn{2}{|c|}{$95 \%$ Confidence Interval } \\
\hline & & & & & Lower Bound & Upper Bound \\
\hline \multirow{2}{*}{ Low } & Average & $4.64941^{*}$ & 1.46817 & .012 & .9605 & 8.3384 \\
\hline & High & $7.08497^{*}$ & 2.58513 & .028 & .6887 & 13.4813 \\
\hline \multirow{2}{*}{ Average } & Low & $-4.64941^{*}$ & 1.46817 & .012 & -8.3384 & -.9605 \\
\hline & High & 2.43556 & 2.27484 & .543 & -3.3358 & 8.2069 \\
\hline \multirow{2}{*}{ High } & Low & $-7.08497^{*}$ & 2.58513 & .028 & -13.4813 & -.6887 \\
\hline & Average & -2.43556 & 2.27484 & .543 & -8.2069 & 3.3358 \\
\hline
\end{tabular}

TABLE 9: TUKEY HSD POST HOC ANALYSIS FOR COMPARISON OF OCCUPATIONAL COMMITMENT AT VARIED LEVELS OF EXTRINSIC REWARDS

\begin{tabular}{|c|c|c|c|c|c|c|}
\hline \multirow{2}{*}{$\begin{array}{l}\text { (I) Ext. } \\
\text { Rewards } \\
\text { Groups }\end{array}$} & \multirow{2}{*}{$\begin{array}{l}\text { (J) Ext. } \\
\text { Rewards } \\
\text { Groups }\end{array}$} & \multirow{2}{*}{$\begin{array}{l}\text { Mean Difference } \\
(I-J)\end{array}$} & \multirow[t]{2}{*}{ Std. Error } & \multirow[t]{2}{*}{ Sig. } & \multicolumn{2}{|c|}{$95 \%$ Confidence Interval } \\
\hline & & & & & Lower Bound & Upper Bound \\
\hline \multirow{2}{*}{ Low } & Average & -2.14235 & 1.42068 & .292 & -5.5335 & 1.2488 \\
\hline & High & $-5.49346^{*}$ & 1.71136 & .005 & -9.5785 & -1.4084 \\
\hline \multirow{2}{*}{ Average } & Low & 2.14235 & 1.42068 & .292 & -1.2488 & 5.5335 \\
\hline & High & $-3.35111^{*}$ & 1.39092 & .047 & -6.6712 & -.0310 \\
\hline \multirow{2}{*}{ High } & Low & $5.49346^{*}$ & 1.71136 & .005 & 1.4084 & 9.5785 \\
\hline & Average & $3.35111 *$ & 1.39092 & .047 & .0310 & 6.6712 \\
\hline
\end{tabular}

TABLE 10: PREDICTING CAREER SATISFACTION OF DENTISTS: MULTIPLE REGRESSION ANALYSIS

\begin{tabular}{|l|l|l|l|}
\hline & Beta $(\boldsymbol{\beta})$ & T & Sig. \\
\hline Constant & - & 8.382 & .000 \\
\hline $\begin{array}{l}\text { Career } \\
\text { Entrenchment }\end{array}$ & -.681 & -8.923 & .000 \\
\hline $\begin{array}{l}\text { Occupational } \\
\text { Commitment }\end{array}$ & .175 & 2.297 & .024 \\
\hline
\end{tabular}

TABLE 11: REGRESSION MODEL SUMMARY

\begin{tabular}{|l|l|l|l|}
\hline R Square & Adjusted R Square & F & Sig. \\
\hline .571 & .561 & 54.63 & .000 \\
\hline
\end{tabular}

